\title{
Small models of hybrids for special subclasses of Jonsson theories
}

\begin{abstract}
This article presents the result related to the model-theoretic properties of special subsets of the semantic model of some fixed Jonsson theory. The specialty of these sets is due to their definability and closure. Further, we consider fragments of these sets and create a hybrid of these fragments from them. The theory is subject to conditions of strongly convexity and existentially coreness. As a result, the class of existentially closed and algebraically prime models in its non-empty intersection contains a core model. By module of the above conditions, the hybrid of the considered fragments has a model that contains a special core subset, definable closure of which gives a certain existentially closed model, which is an algebraic prime model of the theory under consideration.
\end{abstract}

Keywords: Jonsson theory, semantic model, hybrid, existentially prime theory, pregeometry, model companion.

One of the most important aspects of the classical model theory is the description of countable models of the considered theory. In this article, we propose to consider this topic in the framework of the intersection of two issues. Namely, with the help of special subsets of the semantic model of a fixed Jonsson theory, consider hybrids of fragments of these sets and further, using the principle of «Rheostat» for these hybrids, study some properties of small models of these hybrids. Thus, in the intersection there are issues related to the theme of hybrids and the principle of Rheostat when working with small models. These topics were considered in the following articles [1-5].

We give the necessary definitions of the basic concepts of this article.

Let given a countable language of the first order.

The following definition describes one of the basic concepts of this article.

Definition 1. A theory $T$ is Jonsson if:

1) Theory $T$ has infinite models;

2) Theory $T$ is inductive;

3) Theory $T$ has the joint embedding property $(J E P)$;

4) Theory $T$ has the property of amalgam $(A P)$.

Examples of Jonsson theories are:

1) Group Theory;

2) Theory of Abelian groups;

3) Theory of fields of fixed characteristics;

4) Theory of Boolean algebras;

5) Theory of polygons over a fixed monoid;

6) Theory of modules over a fixed ring;

7) Theory of linear order.

The following definition of the universality and homogeneity of model allocates semantic invariant of any Jonsson theory, namely its semantic model. Moreover, it turned out that the saturation or non-saturation of this model significantly changes the structural properties of both the Jonsson theory itself and its class of models.

Definition 2. Let $\kappa \geq \omega$. Model $M$ of theory $T$ is called $\kappa$-universal for $T$, if each model $T$ with the power strictly less $\kappa$ isomorphically imbedded in $M ; \kappa$-homogeneous for $T$, if for any two models $A$ and $A_{1}$ of theory $T$, which are submodels of $M$ with the power strictly less then $\kappa$ and for isomorphism $f: A \rightarrow A_{1}$ for each extension $B$ of model $A$, wich is a submodel of $M$ and is model of $T$ with the power strictly less then $\kappa$ there is exist the extension $B_{1}$ of model $A_{1}$, which is a submodel of $M$ and an isomorphism $g: B \rightarrow B_{1}$ which extends $f$.

Definition 3. Model $C$ of Jonsson theory $T$ is called semantic model, if it is $\omega^{+}$-homogeneous-universal.

As can be seen from the definition of the Jonsson theory, this theory is not complete. But nevertheless, with the help of its semantic invariant (semantic model) we can always determine the center of Jonsson theory, which is a complete theory. 
Definition 4. The center of Jonsson theory $T$ is called an elementary theory of its semantic model. And denoted through $T^{*}$, i.e. $T^{*}=T h(C)$.

The following two facts speak about the «good» exclusivity of the semantic model.

Fact $1[6 ; 160]$. Each Jonsson theory $T$ has $k^{+}$-homogeneous-universal model of power $2^{k}$. Conversely, if a theory $T$ is inductive and has infinite model and $\omega^{+}$-homogeneous-universal model then the theory $T$ is a Jonsson theory.

Fact $2[6 ; 160]$. Let $T$ is a Jonsson theory. Two $k$-homogeneous-universal models $M$ and $M_{1}$ of $T$ are elementary equivalent.

It is well known from the course of model theory that a saturated model is always a homogeneous-universal model, the reverse is also true. But this definition of homogeneous-universal model [7; 299] is considered as a rule in the framework in the study of complete theory. In the framework of the study of Jonsson theory, we are dealing with a particular case of the definition of a homogeneous-universal model belonging to B. Jonsson [8]. The concept of a saturated model is the same in both cases. By virtue of a more general situation of homogeneousuniversality in the case of Jonsson theory, we do not have a saturation criterion in terms of homogeneousuniversal as in [7, 299]. Therefore, those Jonsson theories, the semantic model of which is saturated, allocate in a special subclass of class of all Jonsson theories, and such theories are called perfect. We give a definition of perfectness of Jonsson theory.

Definition 5. Jonsson theory $T$ is called a perfect theory, if each semantic model of theory $T$ is saturated model of $T^{*}$.

The first author of this article obtained a result describing the perfect Jonsson theory.

Theorem 1 [6, 158]. Let $T$ is a Jonsson theory. Then the following conditions are equivalent:

1) Theory $T$ is perfect;

2) Theory $T^{*}$ is a model companion of theory $T$.

From the above list of Jonsson theories, the following examples 2), 3), 4), 6), 7) are examples of a perfect Jonsson theory. But, for example, group theory is not such, due to the fact that it does not have a model companion.

Let $E_{T}$ be a class of all existentially closed models of Jonsson theory $T$.

This class of models in general case for an arbitrary theory can be empty. But the following result [9, 367] is well known, which says that any inductive theory has a nonempty class of existentially closed models. Since the Jonsson theory is a subclass of class of inductive theories, we can say that $E_{T}$ is a non-empty class.

In the case of a perfect Jonsson theory, the class of models of center of this theory coincides with $E_{T}$. This follows from the following theorem.

Theorem $2[6 ; 162]$. If $T$ be a perfect Jonsson theory then $E_{T}=M o d T^{*}$.

Let $L$ be a countable language of first order. Let $T$ be Jonsson theory in the language $L$ and its semantic model is $C$.

Let $T$ be some Jonsson theory in a fixed language and $C$ - its semantic model.

Definition 6 . Let $X \subseteq C$. We will say that a set $X$ is $\nabla-c l$-Jonsson subset of $C$, if $X$ satisfies the following conditions:

1) $X$ is $\nabla$-definable set (this means that there is a formula from $\nabla$, the solution of which in the $C$ is the set $X$, where $\nabla \subseteq L$, that is $\nabla$ is a view of formula, for example $\exists, \forall, \forall \exists$ and so on.);

2) $\operatorname{cl}(X)=\bar{M}, M \in E_{T}$, where $c l$ is some closure operator defining a pregeometry [10; 289] over $C$ (for example $c l=a c l$ or $c l=d c l)$.

Lemma 1. Let $T$ be Jonsson theory, $E_{T}$ be the class of its existentially closed models. Then for any model $A \in E_{T}$ the theory $T h_{\forall \exists}(A)$ is a Jonsson theory.

Proof can be extract from [6].

Let $X_{1}, X_{2}$ be $\nabla$-cl-Jonsson subset of $C$, where $C$ is semantic model of theory $T$. Let $M_{1}=c l\left(X_{1}\right)$, $M_{2}=\operatorname{cl}\left(X_{2}\right)$, where $M_{1}, M_{2} \in E_{T} . T h_{\forall \exists}\left(M_{1}\right)=T_{1}, T h_{\forall \exists}\left(M_{2}\right)=T_{2} . C_{1}$ is semantic model of theory $T_{1}, C_{2}$ is semantic model of theory $T_{2}$.

We define the essence of the operation of the symbol $\square$ for algebraic construction of models, which will play important role in the definition of hybrids. Let $\bullet \in\left\{\cup, \cap, \times,+, \oplus, \prod_{F}, \prod_{U}\right\}$, where $\cup$-union, $\cap$-intersection, $\times$-Cartesian product, +-sum and $\oplus$-direct sum, $\prod_{F}$-filtered product and $\prod_{U}^{F}$-ultraproduct.

The following definition gives a hybrid of the first type [5] for two Jonsson theories.

Definition 7. A hybrid $H\left(T_{1}, T_{2}\right)$ of Jonsson theories $T_{1}, T_{2}$ is called the theory $T h_{\forall \exists}\left(C_{1} \square C_{2}\right)$, if it is Jonsson. Herewith, the algebraic construction $\left(C_{1} \boxminus C_{2}\right)$ is called a semantic hybrid of the theories $T_{1}, T_{2}$. 
Note the following fact:

Fact 3. For the theory $H\left(T_{1}, T_{2}\right)$ in order to be Jonsson enough to be that their semantic hybrid $\left(C_{1} \odot C_{2}\right) \in E_{T}$.

Proof. This follows by Lemma 1.

By small models we mean different types of countable models of a fixed theory of a countable language. These types of models include the following: minimal, core, rigid, atomic, prime, existentially closed, and their various generalizations about this fixed theory. For example, the concept of an algebraically prime model is a generalization of a prime model. In [11], various types of generalization of the atomic model were considered, and in this paper we interpolate these generalizations using the «Rheostat» principle. Below is a list of definitions of various types of small models, as well as special cases of Jonsson sets different closures [12], which are special formula subsets of the semantic model of the considered theory. The definable closures of these subsets will define special types of models and for the corresponding mutually model consistent fixed fragments we will consider hybrids of these fragments and study small models.

When studying the model-theoretic properties of an inductive theory, so called existentially closed models [6] play an important role and for inductive theories, the class of existentially closed models is never empty. Recall it definition.

Definition 8. Model $A$ of a theory $T$ is said to be existentially closed if for any model $B$ and any existential formula $\varphi(\bar{x})$ with constants of $A$ we have $A=\exists \bar{x} \varphi(\bar{x})$ provided that $A$ is a submodel of $B$ and $B=\exists \bar{x} \varphi(\bar{x})$.

An analogue of a prime model (in the sense of a complete theory) for an inductive model, generally speaking, incomplete theory, is the concept of an algebraically prime model, which introduced A. Robinson [12].

Definition 9. $A$ is an algebraically prime model of theory $T$, if $A$ is a model of $T$ and $A$ may be isomorphically embedded in each model of the theory $T$.

Next definition of existentially prime theory is introduced by A.R. Yeshkeyev in the work [6].

Definition 10. The inductive theory $T$ is called the existentially prime if: it has an algebraically prime model, the class of its AP (algebraically prime models) denote by $A P_{T}$; class $E_{T}$ non trivial intersects with class $A P_{T}$, i.e. $A P_{T} \cap E_{T} \neq 0$.

The following definition of convex theory belongs to A. Robinson [13].

Definition 11. The theory $T$ is said to be convex if for any its model $A$ and for any family $\left\{B_{i} \mid i \in I\right\}$ of substructures of $A$, which are models of the theory $T$, the intersection $\bigcap_{i \in I} B_{i}$ is a model of $T$, provided it is non-empty. If in addition such an intersection is never empty, then $T$ is said to be strongly convex.

The following definition is taken from J. Baldwin and D. Kueker's work [11].

Definition 12. $B$ is a $\left(\Gamma_{1}, \Gamma_{2},\right)$ - atomic model of $T$, if $B$ is a model of $T$ and for every $n$ every $n$-tuple of elements of $A$ satisfies some formula from $B$ in $\Gamma_{1}$, which is complete for $\Gamma_{2}$-formulas.

The following definitions 13 and 14 about of various types of small models, as well as special cases of Jonsson sets [12].

Definition 13. A set $A$ is said to be $\left(\nabla_{1}, \nabla_{2}\right)-c l$ atomic in the theory $T$, if

1) $\forall a \in A, \exists \varphi \in \nabla_{1}$ such that for any formula $\psi \in \nabla_{2}$ follows that $\varphi$ is complete formula for $\psi$ and $C \models \varphi(a)$;

2) $\operatorname{cl}(A)=M, M \in E_{T}$, and obtained model $M$ is said to be $\left(\nabla_{1}, \nabla_{2}\right)-c l$ atomic model of theory $T$.

Definition 14 . A set $A$ is said to be $\left(\nabla_{1}, \nabla_{2}\right)-c l$-algebraically prime in the theory $T$, if

1) $A$ is $\left(\nabla_{1}, \nabla_{2}\right)-c l$-atomic set in $T$;

2) $\operatorname{cl}(A)=M, M \in A P_{T}$,

and obtained model $M$ is said to be $\left(\nabla_{1}, \nabla_{2}\right)-c l$ algebraically prime model of theory $T$.

The following definition of model consistent theory from work [14] is well known.

Definition 15. $T$ and $T^{*}$ are mutually model consistent, i.e. every model of theory $T$ is embeddable in a model of theory $T^{*}$, and vice versa.

To obtain the result, the following definition was introduced by the first author of this article.

Definition 16. The theory is called existentially core if this theory is existentially prime and among existentially closed algebraically prime models there is at least one core model.

In order to define needed for us special types of atomicity of certain models we have used the following idea. It is the so-called principle of «rheostat» [12]. Let us recall that idea.

Principle of «rheostat».

Let two countable models $A_{1}, A_{2}$ of some Jonsson theory $T$ be given. Moreover, $A_{1}$ is an atomic model in the sense of [1], and $X$ is $\left(\nabla_{1}, \nabla_{2}\right)-c l$-algebraically prime set of theory $T$ and $c l(X)=A_{2}$. Since $\nabla_{1}=\nabla_{2}=L$, then $A_{1} \cong A_{2}$. 
By the definition of $\left(\nabla_{1}, \nabla_{2}\right)$ - algebraic primeness of the set $X$, the model $A_{2}$ is both existentially closed and algebraically prime. Thus, the model $A_{2}$ is isomorphically embedded in the model $A_{1}$. Since by condition the model $A_{1}$ is countably atomic, then according to the Vaught's theorem, $A_{1}$ is prime, i.e. it is elementarily embedded in the model $A_{2}$. Thus, the models $A_{1}, A_{2}$ differ from each other only by the interior of the set $X$. This follows from the fact that any element of $a \in A_{2} \backslash X$ implements some principal type, since $a \in \operatorname{cl}(X)$. That is, all countable atomic models in the sense of [15] are isomorphic to each other, then by increasing $X$ we find more elements that do not realize the principal type and, accordingly, $\operatorname{cl}(X)$ is not an atomic model in the sense of [15]. Thus, the principle of rheostat is that, by increasing the power of the set $X$, we move away from the notion of atomicity in the sense of [15] and on the contrary, decreasing the power of the set $X$ we move away from the notion of atomicity in the sense of [11].

Let $A A P C \in\{$ atomic, algebraically prime, core $\}$. Thus, by specifying the set $X$ as $\left(\nabla_{1}, \nabla_{2}\right)-c l-A A P C$, (where $A P C$ is a semantic property), we can also specify atomicity in the sense [11] in relation to atomicity $(A)$ in the sense of [15]. And accordingly, using of the principle of «rheostat» after the $A A P C$ property is defined, we obtain the corresponding concepts of atomic models, the role of which is played $A_{2}$ from the principle of «rheostat».

The main result is the following theorem.

Let $\nabla$ from the definition 6 , such that $\nabla \in\{\forall, \exists, \forall \exists\}$.

Theorem 1. Let $T$ be perfect, strongly convex, existentially core, complete for $\forall \exists$-sentences Jonsson theory. $X_{1}, X_{2}$ are $(\nabla, \nabla)$-cl-atomic sets of the theory $T$, where $d c l\left(X_{1}\right)=M_{1}, d c l\left(X_{2}\right)=M_{2}, M_{1}, M_{2} \in E_{T}$. $T h_{\forall \exists}\left(M_{1}\right)=T_{1}, T h_{\forall \exists}\left(M_{2}\right)=T_{2} . C_{1}, C_{2}$ are semantic models of the theories $T_{1}, T_{2}$, correspondingly. $T_{1}$ is model consistent with $T_{2}$ and with $T$. Let $H\left(T_{1}, T_{2}\right)=T h_{\forall \exists}\left(C_{1} \times C_{2}\right)$.

If $M_{1}, M_{2}$ are $(\Sigma, \Sigma)$-cl-atomic models, then there exist $M \in E_{H\left(T_{1}, T_{2}\right)}$ such that $M$ is countable model and $M \in A P_{H\left(T_{1}, T_{2}\right)}$ and $M$ is $(\nabla, \nabla)$-cl-algebraically prime model.

Proof. The conditions in the head of the theorem are independent. That is there are perfect, strongly convex, existentially core, complete for $\forall \exists$-sentences in all possible different combinations among themselves. Therefore, all these conditions are fulfilled at the same time distinguishing a fairly good class, generally speaking incomplete theories, among the Jonsson theories.

It is well known from [16] that convex theories satisfy the following property: for any model of such a theory, its any non-empty subset generates a unique submodel of this theory. Namely, this model is the intersection of all models of this theory that contain a given set. If $T$ is strongly convex, then the intersection of all $T$ models contained in this $T$ model is also a $T$ model. This intersection is called the $T$ core model.

If $T$ satisfies the joint embedding property to the fact that this theory is strongly convex, then its core model is unique up to isomorphism. That is core model has the property that it is isomorphic to exactly one submodel of each $T$ model, and is uniquely defined as the largest model with this property.

Using the principle of a rheostat, we can see that the larger the set $X_{1}, X_{2}$ in power, the more existentially closed models $M_{1}, M_{2}$ of the theory $T$ differ from being atom models of this theory in the sense of [15]. But as $T_{1}$ and $T_{2}$ are model consistent with $T$, any model from $\operatorname{Mod} T_{i}$, where $i \in\{1,2\}$ is isomorphically embedded into some $N \in E_{T}$, where $n \subseteq C$.

Consider the algebraic construction $C_{1} \times C_{2}$, we denote it as $D=\left\{\langle a, b\rangle: a \in C_{1}, b \in C_{2}\right\}$. Since $T$ is a Jonsson theory, then due to its axiomatizable the class of its models is closed with respect to isomorphic images, which means that we can conclude that without loss of generality $C_{1}, C_{2} \in M o d T$. Due to the strong convexity of the theory $T, C_{1} \cap C_{2} \neq \emptyset$ and let $C_{1} \cap C_{2}=F \in M o d T$. Moreover, due to the existentially corecity of the theory $T$ there is a core model $F^{\prime}$ of the theory $T$, which is an existentially closed submodel of $F$. Since $T$ is an axiomatizable theory and $C_{1}, C_{2} \in \operatorname{ModT}$ models, we conclude that $C_{1} \times C_{2} \in \operatorname{ModT}$. Due to the model consistency of $T, T_{1}, T_{2}$, we can conclude, without loss of generality, that $C_{1} \times C_{2} \in \operatorname{Mod} T_{i}$, where $i \in\{1,2\}$. Then, by virtue of Theorem $3.2 \mathrm{~b}$ ) of [11] and the above, the model is $F^{\prime} \in E_{T_{i}}$, where $i \in\{1,2\}$. Then, consider $T h_{\forall \exists}\left(C_{1} \times C_{2}\right)$, due to the model consistency of $T, T_{1}, T_{2}$, and $\forall \exists$-completeness $T$ is Jonsson theory, which is $H\left(T_{1}, T_{2}\right)$. It is easy to see that $H\left(T_{1}, T_{2}\right)$ is model consistency with $T$ theory, then for any two $N_{1}, N_{2}-(\Sigma, \Sigma)$ - $c l$ - atomic models there is a model $K \in E_{H\left(T_{1}, T_{2}\right)}$, which is $(\nabla, \nabla)$ - cl - algebraic prime, as $K$ we can take $F^{\prime}$.

All concepts that are not defined in this article and connected information with these statements can be extracted from [6]. 


\title{
References
}

1 Yeshkeyev A.R. Strongly minimal Jonsson sets and their properties / A.R. Yeshkeyev // Bulletin of the Karaganda University. Mathematics series. - 2015. - Vol. 80. - No. 4. -P. 47-51.

2 Poizat B. Positive Jonsson Theories / B. Poizat, A.R. Yeshkeyev // Logica Universalis. - 2018. — Vol. 12. - No. 1-2. - P. 101-127.

3 Yeshkeyev A.R. Properties of lattices of the existential formulas of Jonsson fragments / A.R. Yeshkeyev, M.T. Kasymetova // Bulletin of the Karaganda University. Mathematics series. - 2015. - Vol. 79. - No. 3. - P. 25-32.

4 Yeshkeyev A.R. On lattice of existential formulas for fragment of Jonsson set / A.R. Yeshkeyev, O.I. Ulbrikht // Bulletin of the Karaganda University. Mathematics series. - 2015. - Vol. 79. - No. 3. - P. $33-39$.

5 Yeshkeyev A.R. Properties of hybrids of Jonsson theories / A.R. Yeshkeyev, N.M. Mussina // Bulletin of the Karaganda University. Mathematics series. - 2018. - Vol. 92. - No. 4. - P. 99-104.

6 Ешкеев А.Р. Йонсоновские теории и их классы моделей: моногр. / А.Р. Ешкеев, М.Т. Касыметова. - Караганда: Изд-во КарГУ, 2016. - 370 с.

7 Кейслер Х.Дж. Теория моделей / Х.Дж. Кейслер, Ч.Ч. Чэн. - М.: Мир, 1977. - 614 с.

8 Jonsson B. Homogeneous universal relational systems / B. Jonsson. - Math. Scand, 1960. - P. $137-142$.

9 Hodges W.A. Model Theory / W.A. Hodges. - Cambridge University Press, 1993. - P. 772.

10 Marker D. Model Theory: In introduction / D. Marker. - Springer-Verlag New York. Inc., 2002. — P. 342.

11 Baldwin J.T. Algebraically prime models / J.T. Baldwin, D.W. Kueker // Ann. Math. Logic. - 1981. 20. - P. 289-330.

12 Yeshkeyev A.R. The atomic definable subsets of semantic model / A.R. Yeshkeyev, A.K. Issayeva, N.M. Mussina // Bulletin of the Karaganda University. Mathematics series. - 2019. - Vol. 94. - No. 2. - P. 84-91.

13 Robinson A. Introduction to Model Theory and to the Mathematics of Algebra / A. Robinson. Amsterdam, 1963.

14 Барвайс Дж. Справочная книга по математической логике: [В 4 ч.]. - Ч. 1. Теория моделей / Дж. Барвайс; пер. с англ. - М.: Наука; Гл. ред. физ.-мат. лит., 1982. - 126 с.

15 Vaught R. Denumerable models of complete theories in Infinitistic Methode / R. Vaught // Pergamon. London, 1961. - P. 303-321.

16 Kueker D.W. Core structures for theories / D.W. Kueker // Fundamenta Mathematicae LXXXIX (1973). - P. 154-171.

А.Р. Ешкеев, Н.М. Мусина

\section{Йонсондық теориялардың арнайы ішкі кластары гибридтерінің кішігірім модельдері}

\begin{abstract}
Мақалада кейбір бекітілген йонсондық теорияның семантикалық моделінің арнайы ішкі жиындардың модельді-теоретикалық қасиеттерімен байланысты нәтижесі берілген. Осы жиындардың арнайылығы олардың анықталуымен және тұйықтылығымен келісілген. Әрі қарай осы жиындардың фрагменттері қарастырылды және осы фрагменттерден гибрид жасалды. Теорияға қатты дөңестілік және экзистенциалды ядролық шарттар қойылды. Нәтижесінде экзистенциалды тұйық және алгебралық жай модельдер класы өздерінің құр емес қиылысуында ядролық модельді құрады. Жоғарыда көрсетілген шарттардың модулі бойынша қарастырып отырған фрагменттің арнайы ядролық ішкі жиынды құрайтын моделі бар, оның анықталған тұйықтамасы қарастырып отырған теорияның алгебралық жай моделі болатын кейбір экзистенциалды тұйық модельді берді.
\end{abstract}

Kiлm сөздер: йонсондық теория, семантикалық модель, гибрид, экзистенциалды жай теория, модельді компаньон. 


\title{
А.Р. Ешкеев, Н.М. Мусина
}

\section{Малые модели гибридов специальных подклассов йонсоновских теорий}

\begin{abstract}
В статье представлен результат, связанный с теоретико-модельными свойствами специальных подмножеств семантической модели некоторой фиксированной йонсоновской теории. Специальность этих множеств обусловлена их определимостью и замыканием. Рассмотрены фрагменты этих множеств и из них создан гибрид фрагментов. На теорию накладываются условия сильно выпуклости и экзистенциально ядерности. В результате класс экзистенциально замкнутых и алгебраически простых моделей в своем непустом пересечении содержит ядерную модель. По модулю указанных выше условий гибрид рассматриваемых фрагментов имеет модель, которая содержит специальное ядерное подмножество, определимое замыкание которого дает некоторую экзистенциально замкнутую модель, являющуюся алгебраической простой моделью рассматриваемой теории.
\end{abstract}

Ключевые слова: йонсоновская теория, семантическая модель, гибрид, экзистенциально простая теория, модельный компаньон.

\section{References}

1 Yeshkeyev, A.R. (2015). Strongly minimal Jonsson sets and their properties. Bulletin of the Karaganda University. Series Mathematics, Vol. 80, 4, 47-51.

2 Poizat, B., \& Yeshkeyev, A.R. (2018). Positive Jonsson Theories. Logica Universalis, Vol. 12, 1-2, 101127.

3 Yeshkeyev, A.R., \& Kasymetova, M.T. (2015). Properties of lattices of the existential formulas of Jonsson fragments. Bulletin of the Karaganda University. Series Mathematics, Vol. 79, 3, 25-32.

4 Yeshkeyev, A.R., \& Ulbrikht, O.I.(2015). On lattice of existential formulas for fragment of Jonsson set. Bulletin of the Karaganda University. Series Mathematics, Vol. 79, 3, 33-39.

5 Yeshkeyev, A.R., \& Mussina, N.M. (2018). Properties of hybrids of Jonsson theories. Bulletin of the Karaganda University. Series Mathematics, Vol. 92, 4, 99-104.

6 Yeshkeyev, A.R., \& Kasymetova, M.T. (2016). Ionsonovskie teorii i ikh klassy modelei [Jonsson theories and their classes of models]. Karaganda: Izdatelstvo KarHU [in Russian].

7 Keisler, H.J., \& Chang, C.C. (1977). Model Theory. Elsiver science publishing company.

8 Jonsson, B. (1960). Homogeneous universal relational systems. Math. Scand., 137-142.

9 Hodges, W.A. (1993). Model Theory. Cambridge University Press.

10 Marker, D. (2002). Model Theory: In introduction. Springer-Verlag New York, Inc.

11 Baldwin, J.T. \& Kueker, D.W. (1981). Algebraically prime models. Ann. Math. Logic., 20, $289-330$.

12 Yeshkeyev, A.R., Issayeva, A.K., \& Mussina, N.M. (2019). The atomic definable subsets of semantic model. Bulletin of the Karaganda University. Series Mathematics, Vol. 94, 2.

13 Robinson, A. (1963). Introduction to Model Theory and to the Mathematics of Algebra. Amsterdam.

14 Barwise, J. (1982). Spravochnaia kniha po matematicheskoi lohike [Handbook of mathematical logic. Model theory]. (Part 1). Moscow: Nauka [in Russian].

15 Vaught, R. (1961) Denumerable models of complete theories in Infinitistic Methode. Pergamon. London.

16 Kueker, D.W. (1973). Core structures for theories. Fundamenta Mathematicae LXXXIX, 154-171. 